УДК 664.843 .626

DOI https://doi.org/10.32838/TNU-2663-5941/2020.6-2/18

\title{
Шинкарук М.В.
}

Херсонський державний аграрно-економічний університет

\section{Кірова Я.В.}

Херсонський державний аграрно-економічний університет

\section{ВИКОРИСТАННЯ НЕТРАДИЦИЙНОЇ РОСЛИННОЇ СИРОВИНИ ФУНКЦІОНАЛЬНОГО ПРИЗНАЧЕННЯ У ВИРОБНИЦТВІ КОНСЕРВОВАНИХ ОГІРКІВ}

Стаття присвячена аналізу консервної промисловості, а саме виробництву плодоовочевих консервів та напрямам вирішення актуальної проблеми населення України рачіонального харчування, а саме підвищення біологічної цінності харчових продуктів та збагачення продуктів функціональними інгредієнтами. Розглянуто етапи створення функціонального продукту. Проаналізовано деякі технології виробництва маринованих огірків іншими вітчизняними науковцями та обтрунтування змінення одного інгредієнту на інший, оцтової есениії, яку отримують при сухій перегонці деревини хімічним шляхом, яка має властивість консерванту, тобто бактерицидну дію, на яблучний та виноградний оцет, а щзе краще у маринадах кислоти замінити на інші кислоти рослинного походження, а можна і на яблуневий сік, також можна зробити заміну на молочну сироватку, де вміст сухих речовин вище, ніж в маринадах на оцті. Вміст загального иукру - відносно однаковий. Проте, завдяки лактозі, щзо міститься в молочній сироватиі, масова частка иукру може збільшуватися. Розглядалася суміш прянощів «Духмяний», яка має вишуканий аромат та щуаний вплив на шлунково-кишковий тракт. Проаналізовано стратегічний напрям розвитку харчової промисловості в даному випадку ТОВ «Плодоовочевий комбінат «Херсон» (смт. Зеленівка Херсонської області). Розглянута харчова і біологічна иінність та лікувальні властивості червоної смородини та квітів чорнобривців. Проаналізовані результати визначення якості квітів чорнобривців. Розглянута основна і допоміжна сировина. Розроблена рецептура консервів «Мариновані огірки “Marigold”", технологічна схема виробництва. Обгрунтовано оптимізацію технологічного процесу. Зроблено висновок, щуо така технологія буде відповідати вимогам стандарту, сприяти раціональному використанню та збагаченню організму людини мікронутрієнтами завдяки підвищенню харчової иінності готового продукту.

Ключові слова: технологія виробництва, мариновані огірки, нетрадиційна рослинна сировина, функціональний продукт, червона смородина, квітки чорнобривців, рецептура, технологічна схема.

Постановка проблеми. Консервна промисловість - одна $з$ найважливіших галузей харчової промисловості України. Основним напрямом цього підрозділу є виробництво плодоовочевих, м'ясних, рибних і молочних консервів. Найбільший відсоток (майже 80\%) займає консервоване виробництво плодоовочевого напряму.

Консервування овочів та фруктів полягає в тому, що воно забезпечує населення біологічно цінними речовинами на цілий рік. Результати досліджень сучасного харчування населення свідчить про недостатнє споживання незамінних компонентів іжі, що знижує опір організму впливу факторів навколишнього середовища, формує синдром хронічної втоми, депресії, знижує розумову і фізичну активність. За дослідженням вчених, населенню України не вистачає поживних речовин, вітамінів у своєму щоденному раціоні, отже, необхідно роз- робляти напрями щодо збагачення продуктів функціональними інгредієнтами. Одним із найважливіших напрямів вирішення проблеми раціонального харчування $є$ підвищення біологічної цінності харчових продуктів. Тому створення доступних і збалансованих у харчовому відношенні та біологічно повноцінних продуктів $є$ актуальною проблемою для населення України [1].

Аналіз останніх досліджень. Створення функціонального продукту має декілька етапів, а саме:

- вибір продукту, який необхідно збагатити;

- вибір функціональних інгредієнтів, які необхідно додати до традиційного продукту;

- вибір природного функціонального продукту як джерела необхідних функціональних інгредієнтів;

- дослідження сумісності за фізико-хімічними та біологічними властивостями доданого 
функціонального інгредієнту 3 компонентами продукту, що підлягає збагаченню;

- складання рецептури функціонального продукту;

- дослідження технологічних режимів підготовки функціонального інгредієнта і його внесення; вибір стадії технологічного процесу, найбільш придатної для внесення функціонального інгредієнту;

- оцінка органолептичних, споживних властивостей отриманого функціонального продукту і його біологічна цінність;

- оцінка економічної та соціальної ефективності виробництва і реалізації нового функціонального продукту, його конкурентоспроможності;

- розробка нормативно-технічної документації на виробництво нового функціонального продукту [2].

Коли новий продукт пройде всі етапи інноваційного розроблення, його необхідно впровадити в виробництво та просувати на ринок для реалізації у вигляді готового товару [3; $4 ; 5]$.

Цій проблемі приділяють увагу багато вчених, таких як О.В. Стоянова та К.В. Зубкова [6], які розробили технологію виробництва маринованих огірків, де одним із головних компонентів маринаду є оцтова есенція, яку отримують під час сухої перегонки деревини хімічним шляхом. Оцтова кислота має властивість консерванту, тобто бактерицидну дію. Відомо, що патогенна мікрофлора найбільш сприятливо розвивається в лужному середовищі, тому підкислення продуктів оцтовою кислотою, що має рН 3,3-4,0, запобігає розвитку мікроорганізмів. Більшість патогенних мікроорганізмів гине в 2\%-му розчині оцтової кислоти. Але вона дуже шкодить організму людини і особливо організму дітей молодшого віку, тому розумніше використовувати яблучний або виноградний оцет, а ще краще у маринадах кислоти замінити на інші кислоти рослинного походження, а можна i на яблуневий сік, який має корисний вплив на організм людини та не забороняються у дитячому та дієтичному харчуванні, також було доведено, що нові консерви характеризуються високими органолептичними властивостями.

Ще одним науковцем, Н.В. Кацеріковою [7], була запропонована заміна оцтової кислоти в маринаді шляхом використання нетрадиційної сировини - молочної сироватки. Було встановлено, що в маринадах на основі молочної сироватки вміст сухих речовин вище, ніж у маринадах на оцті. Вміст загального цукру відносно однаковий. Проте, завдяки лактозі, що міститься в молочній сироватці, масова частка цукру може збільшуватися. Відомо, що молочна кислота є інгібітором, що перешкоджає переходу нітратів у нітрити і нітрозоаміни, тому поєднання овочів i молочної сироватки в маринадах $з$ погляду гігієнічної безпеки є оптимальним.

Науковцями А. Лисенко і С. Бажай [8] була запропонована рецептура з додаванням суміші прянощів «Духмяний», яка містить компоненти у наступних співвідношеннях: петрушка - 15\%, лавровий лист - $2 \%$, селера $-20 \%$, м'ята - 3\%, майоран $20 \%$, базилік - 20\%, кріп - 15\%, коріандр - 5\%. Розроблена суміш прянощів має вишуканий смак та щадний вплив на шлунково-кишковий тракт, що дозволяє розширити коло споживачів, включаючи тих, яким не можна вживати гостру їжу.

Виробництво функціональних харчових продуктів $є$ перспективною галуззю для різноманітних дослідницьких, наукових організацій та інноваційних компаній. Ринок функціональної продукції сьогодні являє собою динамічний і специфічний сегмент діяльності, який вимагає наявності ініціативного та кваліфікованого персоналу, здатного ефективно і досить швидко впровадити на ринок принципово нові продукти [9].

Постановка завдання. Основним завданням публікації є розробка технологічної схеми маринованих огірків "Marigold", обгрунтування оптимізації технологічного процесу, обгрунтування вибору інноваційного інгредієнту рослинного походження.

Виклад основного матеріалу. ТОВ «Плодоовочевий комбінат “Херсон”» (смт Зеленівка Херсонської області) $є$ одним із підприємств області, яке виробляє продукцію за традиційними технологіями, що дозволяє отримувати натуральну, якісну та конкурентоспроможну, таку як томатна паста, соуси, мариновані помідори та огірки, соки та іншу консервацію [10].

Завдяки розширенню асортименту, впровадженню інноваційних технологій, розумінню потреб споживачів підприємство укріплює свої позиції на споживчому ринку, а налагоджений технологічний процес, що забезпечує якість, безпечність та натуральність продукції, дозволяє зберегти в продукції комплекс вітамінів і смакові властивості [11].

Велику увагу приділяють новим розробкам технологічних схем та рецептур. Після проведення всіх необхідних лабораторних досліджень впроваджують у виробництво.

Вищевказане підприємство випускає таку продукцію, як «Огірки мариновані», «Огірки мари- 
новані по-херсонські» та «Огірки мариновані гострі», «Огірки мариновані по-домашньому», «Асорті № 2», «Асорті № 2 «Пікантні». Після ретельного перегляду рентабельності цих продуктів керівництво дійшло такого висновку, що необхідно розробити разом з науковцями Державного вищого навчального закладу «Херсонський державний аграрний університет» новий вид консервів - «Огірки мариновані "Marigold"».

Щоб перейти до розроблення рецептури та технологічної схеми даного продукту, необхідно розглянути всі складники.

Огірки. Для виробництва консервів «Мариновані огірки "Marigold"》 використовують огірки 3 недозрілим насінням, щільною і пружною м'якоттю, зеленого кольору, правильної циліндричної форми у стадії технічного дозрівання.

У виробництво не допускаються огірки в'ялі, перерослі чи перезрілі з розвиненим шкіряним насінням та $з$ пустотами усередині, м'яті, з тріщинками, поражені шкідниками, запарені чи підморожені.

Для консервації придатні лише корнішони двох фракцій: 1 - довжиною від 60 до 90 мм, 2 - довжиною від 90 до 110 мм, при відношенні довжини до найбільшого діаметру не менш 2,5. Огірки повинні відповідати таким вимогам: відібрані, мають зелену шкірку різноманітних відтінків. М'якоть огірків повинна бути пружною і щільною, насіннєва камера - невеликою, насіння - недорозвинуте. Перестиглі огірки не допускаються.

Рекомендовані сорти - Борщаговський, Должник, Донской, Дружба 60, Павловський, Чорнобривець, Ніжинський та інші.

Допоміжні матеріали. Вода питна, сіль, цукор білий кристалічній, оцтова кислота, кріп свіжий, часник свіжий, лавровий лист.

Червона смородина. Ягоди червоної смородини містять значну кількість органічних кислот і цукрів, поєднання яких зумовлює приємний, освіжаючий смак.

Червона смородина багата на вітамін A, C, E, містить залізо, калій, бурштинову і яблучну кислоту, пектинові і азотисті речовини і мінерал селен. У ягодах червоної смородини знайдено 0,2-0,5 мг / 100 г бета-каротину.

Ягоди червоної смородини містять безліч антиоксидантів, здатних протистояти раковим клітинам.

Червона смородина містить аскорбінової кислоти в червоних плодах в 4-5 разів більше, ніж в чорній. У червоній смородині дуже багато заліза, яке так необхідне судинам, і калію, який благо- творно впливає на серце і виводить з організму зайву рідину, не дозволяючи з'являтися набрякам і мішкам під очима.

Червона смородина досить широко застосовується в народній медицині дуже багатьох країн, їі використовують для лікування хворих на діабет, для збудження апетиту, проти нудоти і т.п.

Сік із червоної смородини має в'яжучу, сечогінну, жовчогінну дію. Червона смородина має протизапальну, жарознижувальну, кровотворну, проносну і загально зміцнюючи властивості.

Кумаринові речовини, що входять до складу червоної смородини, знижують згортання крові та сприяють попередженню інфарктів та інсульту, а пектинові, пов'язуючи холестерин, профілактиці атеросклерозу.

Вміщені в ягодах червоної смородини бурштинова і яблучна кислоти, ефективні в літньому віці, при перевтомі; смородиновий сік рекомендують застосовувати спортсменам для підтримки тонусу при марафонських забігах, для прискорення відновлення сил після змагань. Сік смородини п'ють при спастичних колітах і ентероколітах. Він втамовує спрагу, знижує температуру у хворих, особливо у дітей, має протизапальну і потогінну дію, допомагає при анемії.

Свіжі плоди червоної смородини, а також продукти їх переробки покращують апетит, підвищують засвоюваність харчових речовин, кілька підсилюють перистальтику кишечника. Сік володіє освіжаючим смаком і вважається корисним при сечокам'яної хвороби, так як він сприяє виведенню уратів (солей сечової кислоти). Сік ягід добре втамовує спрагу, зменшує температуру при гарячкових захворюваннях, усуває відчуття нудоти, пригнічує блювоту і збуджує перистальтику кишечника.

Сік смородини збільшує виділення поту і сечі і викликає посилене виділення солей з сечею. Сік також має слабку жовчогінну і послаблюючу властивостями і протизапальною і кровоспинну дію. Ягоди і сік $є$ прекрасним засобом для поліпшення апетиту і посилення діяльності шлунка і кишечника. Червона смородина корисна для людей, які страждають тривалими хронічними закрепами. Ягоди повинні бути свіжі, не перестиглі, не м'яті, чисті, без зайвої зовнішньої вологості.

Чорнобривці бархатні - квітка має гіркий аромат, цілющу силу, містить у собі багато ефірної олії і інших корисних речовин. Здатна знизити кількість цукру у крові на початку цукрового діабету, позитивно впливає на підшлункову залозу. У разі порушення обміну речовин (псоріаз, 
Результати визначення якості квітів чорнобривців

\begin{tabular}{|c|c|}
\hline Показник якості & Результати аналізу \\
\hline Зовнішній вигляд & Квіти зазвичай середні і крупні, округлої форми. \\
\hline Колір & Від світло-жовтого до теракотового. \\
\hline Розмір часток & Довжина пелюсток - від 1 до 4 см \\
\hline Запах & Приємний, трошки пряний, без сторонніх віддінків, запаху плісняви чи вологи \\
\hline Смак & Трошки гіркуватий та пряний, злегка в’яжучий \\
\hline Однорідність сировини & Сировина неоднорідна, квіти мають різні розміри \\
\hline
\end{tabular}

Таблиця 2 рювань, різних вірусів і бактерій. Вони роблять

Рецептура виробництва консервів «Мариновані огірки "Marigold"»

\begin{tabular}{|c|c|c|c|}
\hline \multirow{2}{*}{ Назва інгредіснту } & \multicolumn{3}{|c|}{ На 1 т готового продукту, кг } \\
\cline { 2 - 4 } & $\mathbf{1}$ зразок & 2 зразок & 3 зразок \\
\hline Огірки & 450 & 400 & 3500 \\
\hline Залива & 500 & 500 & 500 \\
\hline Червона смородина & 50 & 100 & 150 \\
\hline Цукор білий & 25 & 25 & 25 \\
\hline Сіль & 17,8 & 17,8 & 17,8 \\
\hline Оцтова кислота 99,8 & 1,5 & 1,5 & 1,5 \\
\hline Насіння гірчиці & 2,0 & 2,0 & 2,0 \\
\hline Кріп свіжий & 20 & 20 & 20 \\
\hline $\begin{array}{c}\text { Перець стручковий } \\
\text { гострий }\end{array}$ & 0,665 & 0,665 & 0,665 \\
\hline Часник & 0,570 & 0,570 & 0,570 \\
\hline Лавровий лист & 0,2 & 0,2 & 0,2 \\
\hline Квіти чорнобривців & 0,2 & 0,35 & 0,5 \\
\hline
\end{tabular}

Рецептури заливи

\begin{tabular}{|c|c|c|c|}
\hline $\begin{array}{c}\text { Назва } \\
\text { інгредіснту }\end{array}$ & На 100 л. & На 900 л. & На 1000 л. \\
\hline Сіль & 3,4 & 30,6 & 34 \\
\hline Цукор & 4,4 & 40 & 44,4 \\
\hline $\begin{array}{c}\text { Кислота } \\
\text { лимонна }\end{array}$ & 0,17 & 1,2 & 1,6 \\
\hline $\begin{array}{c}\text { Екстракт } \\
\text { часнику }\end{array}$ & 0,0003 & 0,0027 & 0,003 \\
\hline $\begin{array}{c}\text { Хлористий } \\
\text { кальцій }\end{array}$ & 0,12 & 1,1 & 1,2 \\
\hline Бензоат натрію & 0,03 & 0,27 & 0,3 \\
\hline
\end{tabular}

вітиліго, діатези, нейродерміти, випадіння волосся, погіршення зору) чорнобривці мають цілющі властивості, знижують артеріальний тиск завдяки великій кількості седативних здібностей, що знаходяться в квітці чорнобривців.

Використовувати цю рослину можна не тільки як ліки, iï додають в харчові продукти для підсилення не лише аромату, але й для підвищення лікувальних властивостей, що підвищує імунітет та стійкість організму до застудних захво- їжу корисною і допомагають нормальному травленню. В маринадах надають овочам пряний аромат і пружність [12].

Результати визначення якості квітів наведені в таблиці 1.

Розглянувши всі складники, переходимо до розроблення рецептури. Для виробництва маринованих огірків "Marigold" запропоновано використовувати допоміжну сировину багатофункціонального призначення - квітки чорнобривців (Бархатці) для більш насиченого смаку i запаху. Запропоновані рецептури виробництва маринованих огірків та заливи наведена в таблицях 2 та 3.

Згідно з розробленою рецептурою запропонована технологічна схема виробництва консервів «Мариновані огірки "Marigold"» в умовах лабораторії плодоовочевого комбінату «Херсон», яка включає наступні процеси: приймання сировини - миття сировини - очищення сировини - ополіскування сировини - інспектування сировини бланшування сировини - обрізання кінців - підготовка спецій - приготування заливи - фасування - підготовка кришок і тари - закупорювання - стерилізація - оформлення готової продукції зберігання, яка наведена на рис. 1.

Рецептура приготування консервів 3 вмістом оцтової кислоти є стандартною, а $з$ вмістом лимонної, молочної або яблучної - визначалася дослідним шляхом. На основі проведених досліджень авторами обгрунтовано технологію виготовлення овочевих консервів за новою рецептурою, основними інгредієнтами якої $є$ огірки та червона смородина [12]. Встановлено, що нові консерви характеризуються високими органолептичними властивостями. Після двох місяців зберігання консервів будуть проведені органолептичні та фізико-хімічні аналізи та порівняння отриманих даних з вимогами якості згідно з ДСТУ 3352-96.

Щоб оптимізувати технологічний процес, замочування замінили на бланшування. 
Замочують огірки для того, щоб вони були хрусткими. Якщо ж огірки гіркі, то після замочування, гіркота не зникне, вона залишиться навіть після маринування. Гіркота огірків нейтралізується завдяки тепловій обробці, тому нами було запропоновано замінити технологічний процес замочування на тепловий процес бланшування.

Бланшування овочів-цезануренняїх на2-3 хвилини у воду при температурі $50-60^{\circ} \mathrm{C}$. Це поняття походить від французького blanchir мити, обдавати окропом, вибілювати.

Обробляють таким способом різні плоди і зелень для того, щоб прибрати їх специфічний запах, поліпшити смак, зберегти колір, а також позбутися шкідливих мікроорганізмів, у нашому разі прибрати гіркоту в огірках, але щоб отримати дійсно бланшування, а не варені овочі, слід знати всі тонкощі цього прийому.

Перше важливе правило - дотримуватися технологічних параметрів технології бланшування. Продукти повинні знаходитися у воді не довше 2-3 хвилин. Друге правило - швидко охолоджувати під струменем проточної води. Це необхідно для того, щоб відразу зупинити процес термообробки.

Висновки. Розроблення технологічної схеми нової консервованої продукції буде доцільним, тому що цей продукт є корисним для населення, які мають порушення імунної системи та деякі інші захворювання.

Таким чином, розглянуто технологічні процеси для кожного виду сировини та складена технологічна схема.

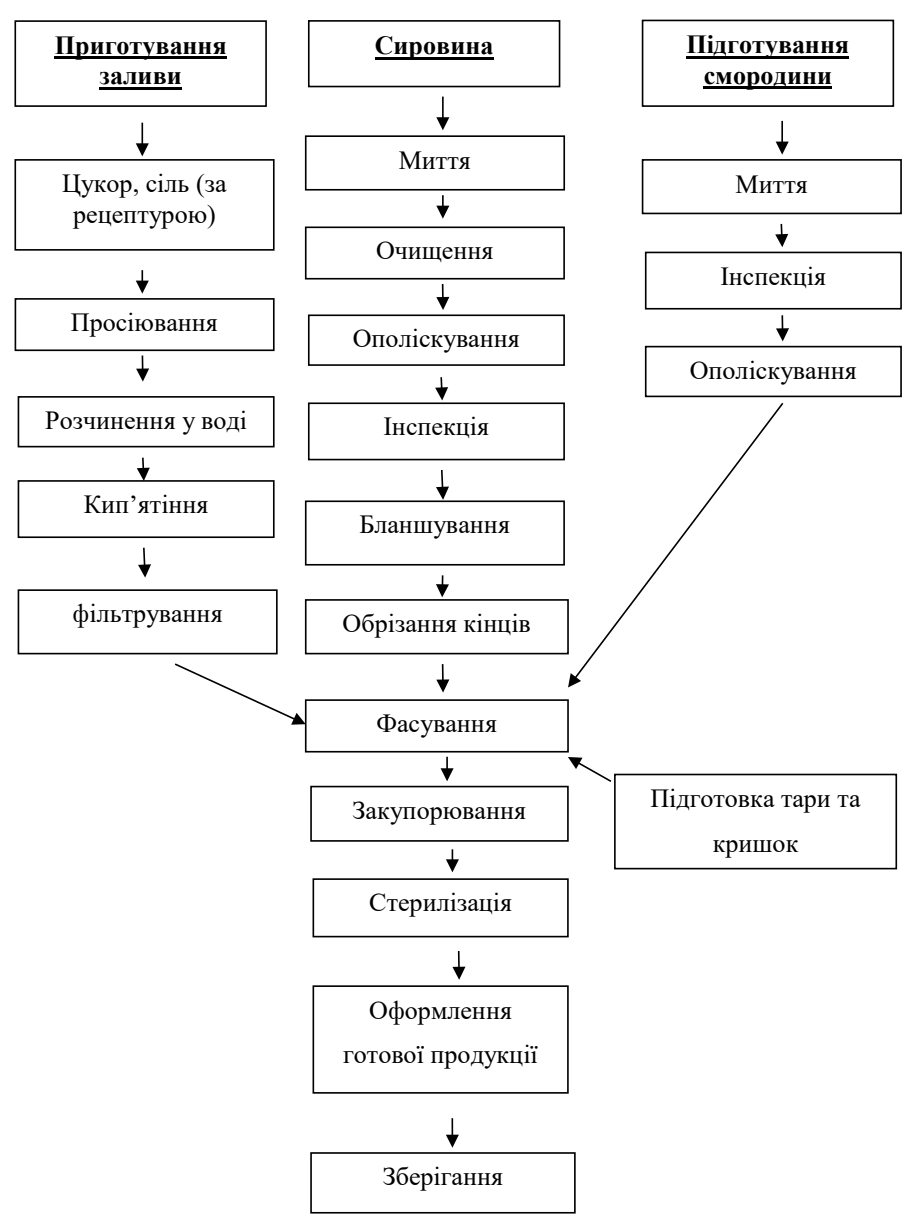

Рис. 1. Технологічна схема виробництва консервів «Мариновані огірки "Marigold"»

У результаті цей продукт спрямований на поліпшення харчової цінності, тобто на забезпечення відповідності їх хімічного складу фізіологічним потребам організму людини.

\section{Список літератури:}

1. Сгоров Б.В., Мардар М.Р. Розробка збагачених харчових продуктів із покращеними споживчими властивостями, Прогресивна техніка та технології харчових виробництв, ресторанного та готельного господарств і торгівлі. Харків : ХДУХТ. 2012. С. 124-126.

2. Основні етапи створення функціональних продуктів. URL: https://studfile.net/preview/2302484/ page: $10 /$

3. Новікова Н.В., Ряполова І.О. Проблеми впровадження інновації у харчовій промисловості. Вісник ХНТУ. Херсон :, 2020, Вип. 1(72), С. 117-123.

4. Воєвода Н.В., Легутенко А.С. Оптимізація технології виробництва ікри оздоровчого спрямування з гарбузом. Вчені записки Таврійського національного університету ім. В.І. Вернадського. № 4. Т. 31(70). 2020 p. C. $208-212$.

5. Voievoda N. Prospects of enterprises development by implementation of new healthcare products technologies. Theoretical and Methodological Approaches to the Formation of a Modern System of Enterprises, Organizations and Institutions' Development: Collective Scientific Monograph (1st edition). Dallas, USA: Primedia eLaunch LLC, 2019. P. 72-83.

6. Валько М.І., Тіхосова Г.А., Стоянова О.В., Зубкова К.В. Удосконалення технології овочевих маринадів. Вісник ХНТУ. 2019, № 2 (57), С. 113-117.

7. Кацерікова Н.В. Технологія продуктів функціонального призначення: Учебное пособие. Кемеровский технологический институт пищевой промышленности. Кемерово, 2004. 146 с. 
8. Артем Лисенко, Світлана Бажай. Суміш прянощів «Духмяні» : Праці 84 міжнародної наукової конференції молодих вчених, аспірантів і студентів. м. Київ, 23-24 квітня 2018 р., Київ : НУХТ 2018. С. 12.

9. Кірова Я.В., Шинкарук М.В. Застосування нетрадиційної сировини у виробництві консервованих огірків. Сучасний стан та перспективи розвитку тваринництва України в умовах євроінтеграції. Херсон, 11 вересня 2020 р. С. 302-304.

10. Плодоовочевий комбінат 3 Херсонщини налагодив успішний експорт своєї продукції. URL: $\quad$ https://ukrainefood.org/2019/10/plodoovochevyj-kombinat-z-khersonshchyny-nalahodyv-uspishnyjeksport-svoiei-produktsii/

11. ТОВ плодоовочевий комбінат «Херсон». URL: https://khoda.gov.ua/36935-2.

12. Що приховують чорнобривці? URL: https://familytimes.com.ua/roslini/scho-prikhovuyut-chornobrivci.

\section{Shyinkaruk M.V., Kirova Ya.V. RATIONALE FOR THE DEVELOPMENT OF THE DEVELOPMENT OF A NEW TECHNOLOGY OF PRODUCTION OF CANNED CUCUMBERS WITH THE ADDITION OF NON-TRADITIONAL PLANTS}

The article is devoted to analysis of the canning industry, namely the production of canned fruits and vegetables and the direction of solving the current problem of Ukraine population of in nutrition, namely increasing the biological value of food and enriching products with functional ingredients. The stages of creating a functional product are considered. Some technologies of pickled cucumber production by other domestic scientists and substantiation of change of one ingredient to another are analyzed,: acetic essence, which is obtained by dry distillation of wood by chemical means, which has preservative properties, and bactericidal effect, on apple and grape vinegar, and even better in marinades, replace the acid with other acids of plant origin or also on apple juice, and also make a substitute for whey, where the dry matter content is higher than in marinades with vinegar. The content of total sugar is relatively the same. However, due to the lactose contained in whey, the mass fraction of sugar may increase. A mixture of spices "Fragrant" was considered, which has a delicate aroma and a gentle effect on the gastrointestinal tract. The strategic direction of food industry development in this case of Fruit and Vegetable Plant Kherson (Zelenivka town, Kherson region) is analyzed. The nutritional and biological value and medicinal properties of red currants and marigold flowers are considered. the results of determining the quality of marigold flowers are analyzed. The main and auxiliary raw materials are considered. The recipe of canned food marinated cucumbers "Marigold", and the technological scheme of production is developed. The optimization of the technological process is substantiated. It is concluded that such technology will rispond the requirements of the standard, promote the rational use and enrichment of the human body with micronutrients by increasing the nutritional value of the finished product.

Key words: production technology, pickles, non-traditional vegetable raw materials, functional product, red currant, marigold flowers, recipe, technological scheme. 